\title{
Pelatihan penulisan karya tulis ilmiah bagi guru-guru SD di desa Geneng kabupaten Jepara
}

\author{
${ }^{1}$ Oktarina Puspita Wardani*, ${ }^{2}$ Turahmat, ${ }^{3}$ Evi Chamalah, ${ }^{4}$ Aida Azizah, ${ }^{5}$ Leli Nisfi Setiana, \\ ${ }^{6}$ Meilan Arsanti, ${ }^{7}$ Hevy Riski Maharani, ${ }^{8} \mathrm{M}$. Abdul Basir, ${ }^{9}$ Dyana Wijayanti \\ $1,2,3,4,5,6,6,7,8,9$ \\ Universitas Islam Sultan Agung (PBSI dan PMat, FKIP, UNISSULA), \\ Semarang, Indonesia \\ *Corresponding Author: \\ Email: oktarinapw@unissula.ac.id
}

\begin{abstract}
Abstrak
Pendidikan dasar merupakan sekolah yang memiliki peran yang strategis dan fundamental bagi pembangunan bangsa. Sehingga penyelenggaraan pendidikan di sekolah dasar harus diarahkan dan menunjang secara optimal demi mencapai tuuan pendidikan nasional. Peraturan baru yang mengharuskan syarat pernah melakukan Penelitian Tindakan Kelas bagi guru sebagai syarat naik golongan menjadi sebuah kendala yang cukup berat. Hal tersebut dikarenakan guru SD tidak terbiasa menulis atau melakukan Penelitian Tindakan Kelas. Guru harus membuat dalam memenuhi kewajibannya jika ingin naik golongan dan pangkat khususnya dari IV a ke IV b atau dari pangkat Pembina ke Pembina tingkat 1 ke atas. Tujuan dari kegiatan ini ialah menjadikan guru mampu membuat karya tulis ilmiah antara lain PTK agar mampu dimanfaatkan untuk pengembangan profesi. Permasalahan yang dihadapi oleh guru ialah bagaimana mengoptimalkan pembuatan penelitian tindakan kelas guru-guru SD di desa Geneng. Kegiatan pengabdian dilakukan dengan menggunakan pendekatan workshop. Kegiatan menggunakan metode ceramah, diskusi dan latihan. Hasil dari kegiatan ini mencapai target. Capaian tersebut ialah guru mampu menghasilkan penelitian tindakan kelas yang baik. Pelaksanaan pengabdian masyarakat diikuti oleh 25 guru. Ketercapaian target pelaksanaan pengabdian masyarakat diikuti oleh 25 guru dari target 30 guru. Sehingga, ketercapaian peserta $83 \%$ atau dapat dinilai baik. Simpulan dalam kegiatan ini ialah ketercapaian target materi yang telah direncanakan pada kegiatan pengabdian ini dapat dinilai baik.
\end{abstract}

Kata kunci: PTK, guru SD, dan karya tulis ilmiah.

Abstract
Basic education is a school that has a strategic and fundamental role for nation
building. Related to the implementation of education in elementary schools must be
aimed at optimally supporting and achieving national education. The new
regulation which requires the requirement to carry out Classroom Action Research
for teachers as a condition for boarding a class is a considerable obstacle. This is
because elementary school teachers are not used to writing or conducting
Classroom Action Research. The teacher must make it in fulfilling his obligations if
he wants to rise in class and rank especially from IV a to IV bor from the rank of
coach to coach level 1 and above. The purpose of this activity is to make teachers
able to make scientific papers including PTK so that they can be utilized for


professional development. The problem faced by the teacher is how to optimize the making of classroom action research for elementary school teachers in Geneng Village. Service activities are carried out using a Workshop approach. The activity uses lecture, discussion and practice methods. The results of this activity reach the target. The achievement is that the teacher is able to produce good classroom action research. The implementation of community service was followed by 25 teachers. The achievement of the target of implementing community service was followed by 25 teachers from the target of 30 teachers. So, the participants' achievement is $83 \%$ or can be considered good. The conclusions in this activity are the achievement of material targets planned for this service activity can be considered good.

Keywords: PTK, elementary school teacher, scientific writing

\section{PENDAHULUAN}

Penelitian Tindakan Kelas adalah penelitian praktis yang dimaksudkan untuk memperbaiki pembelajaran di kelas. Penelitian ini merupakan salah satu upaya guru atau praktisi dalam bentuk berbagai kegiatan yang dilakukan untuk memperbaiki dan atau meningkatkan mutu pembelajaran di kelas. Salah satu bagian penting yang akan menunjang guru mampu meningkatkan kualitas kompetensi profesionalnya adalah kemampuan untuk melakukan penelitian atau melakukan kajian secara intens berkaitan dengan bidang pekerjaan atau disiplin keilmuan yang dimiliki oleh setiap guru.

Guru merupakan pilar utama dalam pendidikan nasional. Pemerintah menerbitkan sejumlah kebijakan untuk mendorong pengembangn profesiolisme guru misalnya melalui program sertifikasi guru. Kebijakan tersebut diikuti dengan aturan guru harus selalu mengembangkan kemmapuan dalam kegiatan pembalajaran di kelas. Sehingga kebijakan tersebut mampu meningkatkan kualitas pendidikan guru seluruh Indonesia.

Peraturan baru yang mengatur kenaikan pangkat jabatan fungsional guru (guru dan kepala sekolah) telah terbit, yakni: (1) Peraturan Menteri Pendayagunaan Aparatur Negara dan Reformasi Birokrasi (Permen PANRB) Nomor 16 Tahun 2009 tanggal 10 November 2009 tentang Jabatan Fungsional Guru dan Angka Kreditnya. (2) Peraturan Bersama Mendiknas dan Kepala BKN Nomor 03/V/PB/2010 dan Nomor 14 Tahun 2010 tanggal 6 Mei 2010 tentang Petunjuk Pelaksanaan Jabatan Fungsional Guru dan Angka Kreditnya. Sedikitnya 344 ribu dari 2,7 juta guru di Indonesia berada pada golongan IV/A. Namun, dari jumlah tersebut baru sekitar 2.200 guru yang bisa naik ke golongan IV/B ke atas. Sisanya, menumpuk di golongan IV/A karena "mandeg" akibat belum mau dan mampu membuat karya tulis ilmiah. Berdasarkan data tersebut golongan IVa sulit naik ke IVb 
disebabkan guru mengalami hambatan diantaranya menulis karya ilmiah dan membuat laporan PTK serta susah mengumpulkan 12 angka kredit untuk naik dari IVA ke IVB.

Akibat keterbatasan kemampuan guru dalam membuat karya tulis ilmiah khususnya Penelitian Tindakan Kelas berakibat pada rendahnya hasil penelitian tindakan kelas yang dilakukan oleh guru. Guru juga banyak yang belum menggunakan media atau metode dalam mengajar sehingga siswa merasa bosan. Oleh karena itu, guru harus selalu kreatif dan inovatif dalam mengemas pembelajaran menarik siswa dengan cara melakukan penelitian menggunakan model atau metide. Untuk itu sangat diperlukan suatu pelatihan bagi guru SD di Desa Geneng sebagai upaya mengembangkan keterampilan dan kreativitas guru dalam membuat penelitian tindakan kelas sehingga mereka dapat lebih variatif menggunakan media dan metode pembelajaran dengan baik.

Karya tulis ilmiah guru hendaknya memiliki persyaratan khusus, yakni syarat APIK (Asli, Perlu, Ilmiah, dan Konsisten) (Arikunto, 2007:83) yang artinya adalah: (1) Asli, karya tulis yang dihasilkan harus merupakan produk asli guru dan sesuai dengan mata pelajaran yang diampu dan tempat bekerja. (2) Perlu, karya tulis yang dihasilkan guru harus dirasakan manfaatnya secara langsung oleh guru dalam meningkatkan kualitas pembelajaran. (3) Ilmiah, karya tulis yang dihasilkan harus disusun secara ilmiah, sistematis, runtut dan memenuhi persyaratan penulisan karya ilmiah, dan (4) Konsisten, karya tulis ilmiah yang dihasilkan harus memperlihatkan keajegan dan konsistensi pemikiran yang utuh, baik secara keseluruhan maupun hubungan antar bab bagian karya tulis yang disajikan

Penelitian tindakan kelas dimanfaatkan untuk meningkatkan kualitas pembelajaran di dalam kelas. PTK bertujuan untuk memperbaiki praktik pembelajaran secara berkesinambungan yang melekat pada keprofesionalan guru. Dengan kata lain, tujuan umum penelitian tindakan kelas adalah memperbaiki dan meningkatkan layanan profesional guru. PTK juga mampu meningkatkan budaya meneliti bagi guru (Widayati, 2012).

Menurut Hakim (2015) kompetensi yang harus dimiliki oleh guru meliputi kompetensi pedagogik, profesional, sosial dan personal. Pertama, kompetensi pedagogik merupakan kemapuan guru dalam pengelolaan pembelajaran peserta didik yang sekurang-kurangnya meliputi: (a) pemahaman wawasan atau landasan kependidikan, (b) pemahaman terhadap peserta didik, (c) pengembangan kurikulum atau silabus, (d) perancangan pembelajaran, (e) pelaksanaan pembelajaran yang mendidik dan dialogis, (f) pemanfaatan teknologi pembelajaran, (g) evaluasi 
hasil belajar; dan (h) pengembangan peserta didik untuk mengaktualisasikan.

Kompetensi yang mampu ditingkatkan dalam pembelajaran menurut Sukanti (2008) antara lain (1) memahami gaya belajar dan kesulitan belajar peserta didik, (2) menguasai teori dan prinsip belajar serta pembelajaran yang mendidik, (3) mengembangkan kurikulum yang mendorong keterlibatan peserta didik dalam pembelajaran, (4) merancang pembelajaran yang mendidik, (5) melaksanakan pembelajaran yang mendidik, (6) mengevaluasi proses dan hasil pembelajaran, (7) mengevaluasi kinerja sendiri, (8) mengembangkan diri secara berkelanjutan, (9) menguasai substansi bidang studi dan metodologi keilmuannya, (10) menguasai struktur bidang studi dan materi kurikulum bidang studi, (11) menguasai dan memanfaatkan teknologi informasi dan komunikasi dalam pembelajaran, (12) mengorganisasikan materi kurikulum bidang studi, (13) meningkatkan kualitas pembelajaran.

Karya tulis ilmiah mempunyai karakteristik tertentu yang membedakan dengan karya tulis lainnya atau non ilmiah. Karakteristik ini perlu diketahui untuk membekali kemampuan menilai suatu karya tulis, apakah termasuk karya tulis atau bukan, dan memberikan dasar dalam menyusun karya tulis ilmiah atau bukan, dan memberikan dasar dalam menyusun karya tulis ilmiah yang baik dan benar. Karya tulis ilmiah adalah sebuah karya tulis yang disajikan secara ilmiah dalam sebuah forum atau media ilmiah. Karakteristik keilmiahan sebuah karya terdapat pada isi, penyajian, dan bahasa yang digunakan (Djuroto, 2014).

Tatang (2006) menyebutkan sifat-sifat khas karya tulis ilmiah yang membedakannya dari karya tulis non ilmiah yaitu: a) karangan atau tulisan, b) dalam bidang ilmu tertentu, c) berlandaskan fakta-fakta obyektif dan atau hasil penalaran logis, d) berupa hasil penelitian, kajian literatur, dan atau pemikiran, e) disusun secara sistematis, f) dalam ragam karangan ilimiah atau ilmiah populer, g) disajikan dengan bahasa yang baik dan benar. Menurut Indrawati (2012), penelitian tindakan kelas memperoleh banyak manfaat, diantaranya guru mendapatkan kemampuan untuk memperbaiki proses pembelajaran melalui kajian mendalam yang terjadi di dalam kelas. Guru juga mampu meningkatkan kinerja secara profesional karena guru mampu memperbaiki pembelajaran dan merefleksi diri sehingga guru menjadi peneliti pada bidangnya. Tujuannya untuk memperbaiki pembelajaran menjadi yang inovatif dan kreatif.

Berdasarkan Keputusan Menteri Negeri Pendayagunaan Aparatur Negara Nomor 84/1993 tentang Jabatan Fungsional Guru dan Angka Kreditnya, dan dengan 
diberlakukannya Undang-undang RI Nomor 14 Tahun 2005 tentang Guru dan Dosen, menunjukkan bahwa guru merupakan jabatan profesional. Sebagai seorang profesional, guru harus mampu membuat prefessional judgement yang didasarkan pada data sekaligus teori yang akurat. Selain itu, guru juga harus melakukan peningkatan mutu pembelajaran secara terus-menerus agar prestasi belajar peserta didik optimal. Untuk mewujudkan hal tersebut guru dituntut memiliki kemampuan melakukan penelitian sederhana dalam rangka meningkatkan kualitas profesional guru, khususnya kualitas pembelajaran (Arikunto, 2006:1-2). Penelitian sederhana tersebut dinamakan Penelitian Tindakan Kelas (PTK). PTK memiliki peran yang sangat penting dan strategis dalam upaya meningkatkan kualitas proses belajar mengajar.

Peningkatan kualitas pembelajaran dengan cara meningkatkan kemampuan pendidik atau guru mampu berdampak baik. dampak baik tersebut dapat berupa menyelesaikan masalah pendidikan dan masalah pembelajaran yang dihadapi secara nyata; (2) peningkatan kualitas masukan, proses, dan hasil belajar; (3) peningkatan keprofesionalan pendidik; (4) penerapan prinsip pembelajaran berbasis penelitian (Depdiknas Ditjen Dikti: 2006, 4). Upaya dalam meningkatkan kompetensi guru atau pendidik untuu penyelesaian masalah pembelajaran dan mengembangkan keprofesiannya dengan melakukan Penelitian Tindakan Kelas.

Pendidikan dasar merupakan sekolah yang memiliki peran yang strategis dan fundamental bagi pembangunan bangsa. Sehingga penyelenggaraan pendidikan di sekolah dasar harus diarahkan dan menunjang secara optimal demi mencapai tuuan pendidikan nasional. Di bagian lain, seiring dengan perkembangnya Iptek dan tuntutan akan kelulusan pendidikan asar yang berkualitas, khususnya sekolah dasar secara berkesinambungan berupaya meningkatkan kualitas layanan pendidikannya. Lkeberhasiulan sekolah dasar dalam menyelenggarakan layanan pendidikan dan menghasilkan lulusan yang berkualitas, berkompeten dan berkrakter. Hal tersebut mampou menentukan eksistensi sekolah tersebut dalam komunitanya di Indonesia.

Salah satu kemampuan yang harus dimiliki seorang guru SD dalam upaya meningkatkan profesionalisme dan kualitas pembelajaran di SD adalah kemampuan guru dalam melaksakan penelitian tindakan kelas. Penelitian Tindakan Kelas (PTK) merupakan penelitian yang dilakukan oleh guru di dalam kelasnya sendiri melalui refleksi diri, dengan tujuan untuk memperbaiki kinerjanya sebagai guru, sehingga hasil belajar siswa dapat 
meningkat.

Guna membantu guru yang mengalami kesulitan dalam membuat karya tulis ilmiah maka dilakukan suatu kegiatan pelatihan untuk pembuatan karya ilmiah berupa penelitian tindaklan kelas guru-guru SD di desa Geneng kabupaten Jepara. Salah satu pelatihan membuat karya tulis ilmiah yang akan ditawarkan adalah pelatihan membuat Penelitian Tindakan Kelas. Dengan membuat karya tulis ilmiah, maka pembelajaran yang dilakukan guru akan lebih efektif dan bermakna. Hal-hal dapat disajikan dalam bentuk model-model, sehingga siswa dapat lebih mudah dalam memahami materi dan mendapatkan hasil belajar yang lebih baik.

Permasalahan yang dapat diidentifikasi adalah bagaimana meningkatkan kemampuan guru dalam menulis karya tulis ilmiah (PTK) bagi guru SD Negeri di Desa Geneng. Tujuan pengabdian ini adalah untuk mengetahui dan mendeskripsikan pemahaman dan kemampuan guru dalam menulis penelitian tindakan kelas. Manfaat yang dapat diberikan pada pelatihan ini ialah mamp memberikan pemahaman dalam menulis laporan penelitian tindakan kelas.

\section{METODE}

Kegiatan pengabdian dilakukan dengan menggunakan pendekatan workshop. Kegiatan menggunakan metode ceramah, diskusi, dan latihan. Metode ceramah dilakukan dengan mmberikan materi kepada guru mengenai karya tulis ilmiah, khususnya Penelitian Tindakan Kelas (PTK). Materi diarahkan untuk mendukung guru mampu menyusun PTK. Diskusi dan latihan dilakukan dengan cara menerapkan materi yang telah diberikan oleh penatar. Tiap materi disampaikan pada peserta dengan berdialog dan diskusi dengan tim pengabdian. Peserta dibagi menjadi beberapa kelompok untuk bekerja sama dalam memecahkan masalah atau mengerjakan tugas. Pada proses latihan praktik menulis, guru diminta untuk melakukan praktik menulis. Guru dikelompokkan menjadi beberapa kelompok belajar. Tingkat kesulitan dalam praktik ini disesuaikan dengan masing-masing peserta. Bagian akhir dalam pelatihan ini akan diberi tugas untuk membuat karya tulis ilmiah berupa penelitian tindakan kelas berdasarkan bidang keashlian masing-masing.

Proses ini diharapkan guru mampu menerapkan lagkah-langkah yang harus dilakukan guru dalam menyusun PTK. Langkah yang dilakukan saat pelaksanaan antara lain a) peserta diberi materi mengenai karya tulis ilmiah, b) peserta mendiskusikan materi 
Indonesian Journal of Community Services

E-ISSN: 2684-8619

Volume 1, No. 1, May 2019

http://jurnal.unissula.ac.id/index.php/ijocs DOI: http://dx.doi.org/10.30659/ijocs.1.1.116-125

yang telah diberikan, c) peserta berlatih membuat laporan penelitian tindakan kelas, d) peserta dibimbing agar hasilnya lebih baik.

\section{HASIL DAN PEMBAHASAN}

Hasil pelaksanaan kegiatan pengabdian masyarakat dirasakan oleh tim pengabdian FKIP UNISSULA maupun peserta pelatihan sangat memuaskan. Dengan indikator kedatangan peserta dalam setiap pertemuan, dan mengikuti pelatihan dengan antusias.

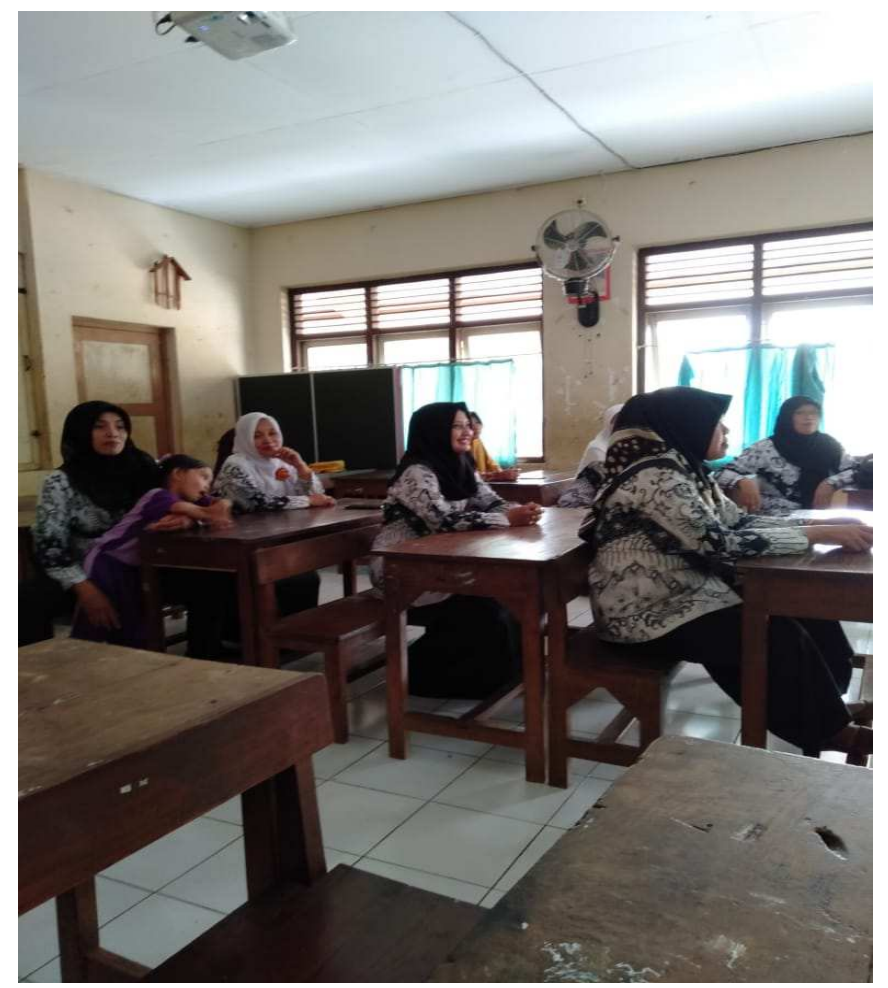

Gambar 1. Peserta workshop menyimak materi pelatihan

Kemampuan peserta dilihat dari penguasaan materi dapat dinilai baik. Hal ini dapat dilihat dari kemampuan bapak/ibu guru dalam kegiatan praktik berupa penyusunan judul PTK, latar belakang masalah, rumusan masalah, tujuan, dan bentuk tindakan yang akan dilakukan, disamping antusiasme dalam acara tatap muka dengan memberikan beberapa pertanyaan. Secara keseluruhan, kegiatan pengabdian bagi guru-guru SD di desa Geneng kecamatan Kalinyamatan kabupaten Jepara dapat dinilai cukup baik. Hal ini berkat dukungan banyak pihak, yaitu dosen FKIP UNISSULA, kepala sekolah dan KKG di Desa 
Geneng.

Kemampuan guru dalam menentukan topik penelitian sudah cukup baik. sebelum dilakukan pelatihan, guru mengalami kesulitan menuangkan ide, tetapi setelah pelatihan guru mampu membuat topik yang baik. kesulitan lain yang dihadapi guru ialah menentukan metode pembelajaran yang mampu meningkatkan minat pembelajaran siswa. Keterbatasan pengetahuan mengenai metode maupun model pembelajaran menjadikan guru harus menggiatkan lagi minat baca mereka. Setelah melalui pelatihan, guru mampu menentukan metode dan model pembelajaran yang sesuai dengan cara diberikan contoh beberapa metode maupun model pembelajaran. Peningkatan yang terlihat ialah guru mampu mengembangkan ide dalam topik penelitian dan dikembangkan lagi menjadi judul penelitian. Guru juga sudah mampu menentukan metode penelitian serta menyusun daftar pustaka.

Pelaksanaan pengabdian masyarakat diikuti oleh 25 guru dari target 30 guru. Sehingga, ketercapaian peserta adalah $83 \%$ atau dapat dinilai baik. Hal tersebut dikarenakan beberapa guru memiliki kegiatan masing-masing yang tidak bisa ditinggal. Ketercapaian target materi yang telah direncanakan pada kegiatan pengabdian ini dapat dinilai baik. Semua materi yang telah direncanakan dapat disampaikan kepada peserta, meskipun karena keterbatasan waktu ada beberapa materi yang hanya disampaikan secara garis besar. Kendala yang dihadapi oleh guru dalam menyelesaikan tugas individu adalah kesibukan disekolah sehingga tidak banyak hasil PTK yang jadi. Sehingga, ketercapaian masih dirasa kurang, sehingga harus mampu menggalakkan lagi budaya menulis.

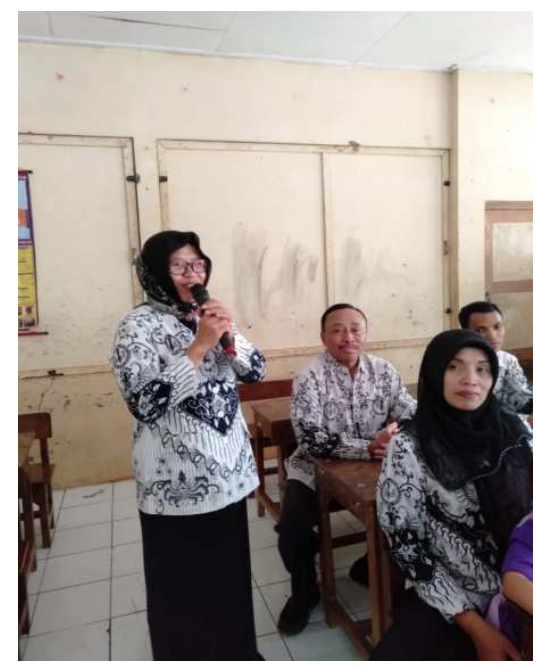

Gambar 2. Peserta pelatihan sedang mengajukan pertanyaan 
Evaluasi kegiatan pelaksanaan kegiatan PKM ini dilakukan penyebaran angket pada peserta (guru). Guru diminta mengisi angket respon dari kegiatan pelatiohan yang dilakukan oleh TIM FKIP Unissula. Hasil dari angket respon tersebut dianalisis dan selanjutnya dideskripsikan. Pendeskripsikan resespon dibagi menjadi tiga, aspek pelaksanaan kegiatan, narasumber, dan aspek umum.

Faktor yang mendukung yang dapat dilihat ialah sambutan dari peserta juga baik sehingga kegitan bisa berjalan dengan baik. Hal tersebut dapat dilihat dari rencana keberlanjutan kegiatan pada masa yang akan datang. Peserta sangat antusias dengan adanya kegiatan ini karena mereka paham pentingnya peningkatan kualitas hasil karya profesi serta kemauan untuk memulai menulis faktor yang menghambat dalam kegiatan pengabdian masyarakat di antaranya tidak terbiasanya guru untuk menulis sehingga waktu yang diberikan terasa kurang.

\section{KESIMPULAN}

Pelaksanaan kegiatan pengabdian masyarakat di desa Geneng kabupaten Jepara dirasakan oleh tim pengabdi maupun peserta dan Kepala UPT serta pengawas pendidikan kecamatan Batealit sangat memuaskan. Dengan indikator kehadiran peserta dan antusias peserta pelatihan cukup baik. Hasil dari pelatihan pembuatan karya tulis ilmiah berwujud makalah, diktat, dan PTK sudah cukup baik. Suasana belajar dan tutorial cukup bagus. Hampir semua peserta mengikuti dari awal sampai akhir. Para pejabat terkait sangat mendukung pelaksanaan pengabdian masyarakat yang dilaksanakan oleh tim.

Agar peserta pelatihan mengembangkan terus pembuatan karya tulis ilmiah yang menjadi kewajiban guru dalam meningkatkan profesionalismenya yang sekaligus akan meningkatkan wawasannya sebagai pendidik. Para pejabat pendidikan agar memotivasi para guru supaya mau menulis karya tulis ilmiah untuk kemajuan para guru dan peserta didiknya serta nama baik daerahnya.

\section{UCAPAN TERIMA KASIH}

Pengabdian dapat terlaksana dengan baik karena bantuan dari berbgai pihak. Saya sampaikan terima kasih atas bantuan dari pihak-pihak berikut.

1. Universitas Islam Sultan Agung Semarang

2. LPPM Unissula 
3. FKIP unissula

4. Prodi PBSI dan PMAT Unissula

5. Kepala sekolah dan SD Negeri di desa Geneng

\section{DAFTAR PUSTAKA}

Arikunto, S. (2007). Prosedur penelitian suatu pendekatan praktik. Jakarta: Rineka Aksara

Arikunto, S., Suhardjono, dan Supardi. (2006). Peneilitian Tindakan Kelas. Jakarta: Bina Aksara.

Depdiknas Dirjen Dikdasmen Direktorat Tnaga Kependidikan. (2001). Pedoman Penyusunan Karya Tulis Ilmiah di Bidang Pendidikan dan Angka Kredit Pengembangan Profesi Guru. Jakarta

Depdiknas Ditjen Dikti Direktorat Ketenagaan. (2006) Pedoman Penyusunan Usulan dan Laporan Penelitian Tindakan Kelas. Jakarta

Djuroto, T. (2014). Menulis Artikel Karya Ilmiah. Bandung: Rosda Karya.

Hakim, A. (2015). "Contribution of Competence Teacher (Pedagogical, Personality, Professional Competence and Social) On the Performance of Learning". The International Journal of Engineering and Science (IJES). Volume 4 Issue 2 PP.0112 ISSN: 2319 - 1813 ISSN: $2319-1805$.

Indrawati, H. (2013). Upaya Peningkatan Kompetensi Profesional Guru Mata Pelajaran Ekonomi dalam Proses Pembelajaran. Jurnal Pendidikan, 4(2), 84-95.

Sukanti. (2008). Meningkatkan Kompetensi Guru Melalui Pelaksanaan Penelitian Tindakan Kelas. Jurnal Pendidikan Akuntansi Indonesia. VI(1), 1 -11

Tatang, M. A. (2006). Menulis Karya Ilmiah (Artikel). Makalah Pelatihan Penulisan Karya Ilmiah Bagi Guru-Guru se-Indonesia. Yogyakarta.

Widayati, A. (2008) Penelitian Tindakan Kelas. Jurnal Pendidikan Akuntansi Indonesia. VI(1), 87-93.

Wiriatmadya, R. (2007). Metode Penelitian Tindakan Kelas untuk Meningkatkan Kinerja Guru dan Dosen. Bandung: Program Pascasarjana Universitas Pendidikan Indonesia bekerjasama PT Remaja Rosdakarya. 